\title{
War Crimes Trial in Bangladesh: A Real Political Vendetta
}

\author{
Dr. Md. Abdul Jalil \\ Department of Business Administration of International Islamic University Malaysia (IIUM) \\ E-mail: abduljalil@iiu.edu.my; abd_jali12@yahoo.com
}

\begin{abstract}
According to national and international press report, the present Awami League (AL) government in Bangladesh has been oppressing opposition political party leaders and their supporters as a means of revenge against them since it assumed in power in January 2009. So far it has killed more than 200 people extra-judicially and arrested more than 1200 leaders and supporters of Jamaat-e-Islami Bangladesh (Jamaat) and Shibir without any valid reason and they are being oppressed in detention since February 2010. This paper mainly focuses on the war crimes trial issue in Bangladesh for war crimes committed in 1971 during independence movement in Bangladesh. Descriptive and analytical research methodology has been applied in this paper. It is an empirical research. It critically explains the mala fide intention of the AL government in prosecuting and arresting some of the opposition political party leaders in Bangladesh for their alleged role in 1971.
\end{abstract}

Keywords: Liberation movement, War crimes trial, Mala fide and politically motivated war crimes tribunal, Oppression of AL government, Fairness and transparency in the war crimes tribunal, Democratic and human rights violation, Political persecution

\section{Introduction}

In 1947 Pakistan was created from India after a long struggle and the sacrifice of people who participated in the liberation movement against the UK. Pakistan consisted of two parts: West Pakistan and East Pakistan (known as Bangladesh). Pakistan as a federal country continued its political activities till 1971 when the people of Bangladesh under the Awami League (AL) started a separation movement for certain reasons, such as disparity in development in two parts, declaring 'Urdu' language as the only national language of Pakistan when in fact it was the minority language of Pakistan and not recognizing the national election result which was held in 1971.

Jamaat-e-Islami Bangladesh (Jamaat) opposed the separation of Bangladesh from Pakistan in 1971 along with other five political parties but history proves that it was not involved in any war crimes, such as killing of people, rape, torture of freedom fighters etc. Even many people in Bangladesh say that the supporters of united Pakistan for example Jamaat gave shelter to freedom fighters in their houses during the day time so that Pakistani soldiers could not find them out. It just peacefully protested against the separation of Bangladesh for certain good reasons as explained below. However, Pakistan failed to maintain its integrity and surrendered to the Indian Army on 16 December 1971 and on this day Bangladesh became an independent country.

In 1973 during the AL regime, thousands of people were arrested for alleged war crimes, such as assisting the Pakistani army, killing freedom fighters, committing rape, arson and looting. At that time, the AL government identified only 195 people as war criminals after collecting evidence against them. Those suspects were all Pakistani army officers. It is a historical fact that no Jamaat leader or any of its supporter was on the war criminal list.

These 195 Pakistani soldiers who were identified as war criminals were given amnesty and repatriated to Pakistan following a tripartite treaty between Bangladesh, India and Pakistan (known as the Bangladesh-India-Pakistan Agreement, 1974). Before this tripartite agreement another agreement was made, named the Indo-Pak Joint Agreement in 1973. India and Pakistan promised in this agreement to repatriate 195 war criminals to Pakistan. Before that the Simla Agreement 1972 was made between India and Pakistan with a promise to end the conflict between the two countries and resolve the issue of war prisoners.

The political background of Jamaat in Bangladesh needs to be explained briefly because the AL government has targeted Jamaat leaders to punish them for alleged war crimes committed 39 years ago. The people of Bangladesh are asking why the AL government did not try and punish Jamaat leaders during 1972-1975 and 1996-2001 when they were in power as the government of Bangladesh? Jamaat sources say that $95 \%$ of Jamaat supporters were in fact freedom fighters and supporters of freedom fighters during the separation movement in 1971 (Abu Rawsab, 12 February, 2010). At present Jamaat is one of the largest political parties in Bangladesh and the AL government is afraid of it. It is known to the Bangladeshi people that AL cannot form government alone, it needs support from Jamaat but Jamaat is not willing to form coalition government with AL because of ideological differences. So, to persecute Jamaat leaders with a political and mala fide motive, AL government 
has already formed the War Crimes Tribunal and appointed prosecutors and judges for the tribunal on 25 March 2010 (RRNN, 25 March 2010). Now it wants to arrest some of the top Jamaat leaders to prosecute them for war crimes although they were not involved in war crimes in 1971 as explained above. Hence, the question is: What is the real intention of AL government in trying the top leaders of Jamaat in 2010 after 39 years of independence of Bangladesh?

According to BBC news (30 June 2008), Jamaat claims to be a "moderate Islamic political party that believes in democracy and human rights" (Durmmett, 30 June, 2008). Jamaat leader Barrister Abdur Razzak said that Jamaat is the victim of a political vendetta. None of its leaders has been prosecuted for the last 39 years for their alleged activities of war crimes during the war in 1971 and the accusations against them seen in the newspapers are baseless and politically motivated (Durmmett, 30 June, 2008).

It is to be noted that recently Pakistan is not happy with the reopening of the war crimes trial by AL government, after 39 years of its settlement and amnesty given to the accused by the Bangladesh government between 1972-1975. Mr. Masod Khalid, Additional Secretary for Asia Pacific in Pakistan's Foreign Office said that the war crimes trial in Bangladesh could hamper ties and cast shadow on relations between the two countries (IAN, 8 June, 2009; Zeenews, 8 June, 2009).

Mr. Sam Zarifi, the Director of Asia Pacific Program of Amnesty International (AI) visited Bangladesh in May 2009. After visiting Bangladesh and talking to government and opposition leaders, Mr. Sam gave an interview with the press and suspected that the war crimes tribunal to be held in 2010, 39 years after Bangladesh became independent might be politicized and a few selected Islamic political leaders might be the victims of the trial (Hossain, May 16, 2009).

In this paper the situation of the freedom fighting movement in 1971 in Bangladesh, the role of Jamaat at that time, the reason why the trial of war criminals issue is raised after 39 years of independence of Bangladesh and many other related issues with the war crimes trial have been discussed and analyzed. The objective of this paper is to disclose and analyze the hostile and male fide political intention of the AL government which is destabilizing the unity of people in Bangladesh and seriously jeopardizing the development and peace process in Bangladesh (Jalal Uddin, 5 March 2008; Zahid bin Zamir, 16 February 2010).

As stated in the abstract, descriptive and analytical research methodology has been used to write this paper. Data has been collected from newspapers, magazines and writings of prominent scholars. Some secondary data has been included as tables in the Appendix. Interview reports of prominent national and international figures have been incorporated in this paper such as Amnesty International Asia Pacific Program Director Mr. Sam Zarifi; European Union Troika delegation leader Ms. Helena Bambasova who is also the Deputy Minister for Foreign Affairs of the Czech Republic; The Bengali Hero and a Commander of Freedom Fighters in 1971 in Bangladesh, Mr. Kader Siddiqui; a prominent political scientist and former Vice-Chancellor of Dhaka University Bangladesh Prof. Dr. Emajuddin; former Chief of Army L. General Mahbubur Rahman and others.

\section{Jamaat is a democratic party}

It is historical fact that Jamaat strongly supports democracy, because in Islam no one has the right to lead a society unless he or she is an elected representative of the people. This is precisely the reason why for more than half a century Jamaat has been following a democratic path. It has participated in almost all the national and local elections. To attain its objectives, Jamaat has never resorted to violence or unconstitutional means. It has always abided by the laws of the country and in the face of extreme provocation and political persecution it defended its rights through legal means. It never adopted or resorted to destructive political means although other political parties in Bangladesh adopted such destructive means to achieve their political goals such as arson, vandalism, fighting with arms, nationwide indefinite strike etc.

It is a historical and undeniable fact that Jamaat was the first political party to demand that Parliamentary elections should be held under a neutral Caretaker Government and for that purpose it prepared a Caretaker Government Bill 1990. In the movement for incorporating the concept of Caretaker Government in the Constitution of Bangladesh Jamaat, AL, and Jatiya Party (JP) worked together, had joint meetings many times and addressed press conferences together from the same platform to pass the Caretaker Government Bill. Finally, the BNP government was bound to accept the Caretaker Government Bill in 1990 and it was incorporated into the Constitution of Bangladesh through amendment to the Constitution. The first three national elections were held under the Caretaker Government and they were free, fair, impartial and credible but unfortunately the last national election which was held on 29 December 2008 was not fair as the Caretaker Government was controlled by the Chief of Army Major General Moin U Ahmed. 


\section{Allegations of war crimes against Jamaat leaders}

As stated earlier on $16^{\text {th }}$ December 1971, the Pakistani Army surrendered in Dhaka with 93,000 soldiers and they were taken as prisoners of war (POWs). Out of that number, there were allegations of war crimes against only 195, and they were identified as war criminals by the Government of Bangladesh. On $19^{\text {th }}$ July 1973, the Parliament of Bangladesh passed the International Crimes (Tribunal) Act 1973 to try the alleged war criminals.

It should be mentioned that the Tribunal under the International Crimes (Tribunal) Act 1973 (Bangladesh) has jurisdiction to try and punish any one who was a member of any armed, defense or auxiliary forces and who has committed war crimes or crimes against humanity. According to Jamaat sources, no leaders or members of Jamaat had ever been a member of any armed, defense or auxiliary forces. Therefore, the question of trying them under the Act does not arise. As a matter of fact a Tribunal formed under the International Crimes (Tribunal) Act 1973 has no jurisdiction to try any member of Jamaat because of the clear statement in the Act that its objective is to try and punish 'persons who were members of any armed, defense or auxiliary forces'.

Recently, the Home Minister of Bangladesh openly ordered the Police Department to annihilate the Jamaat and Shibir (a student organization of Jamaat) in Bangladesh. Such an order by the senior Minister of Bangladesh was very unfortunate, discriminatory, unjust, oppressive and autocratic. The people of Bangladesh cannot expect anything good from such a government for the socio-economic and political development of Bangladesh (Daily Sangram, February 2010). The whole move of the AL government so far interpreted by the international community as nothing but an extreme political vendetta intended to subdue the opposition parties (Serajul and Said, 1 April 2010).

\section{Awami League (AL) is a Double Standard and Oppressive Political Party in Bangladesh}

AL was in power for two terms: from 1972-1975 and 1996-2001. During these two terms they took no step whatsoever to try the leaders of Jamaat for alleged war crimes. During the mass movement for restoration of democracy in the 1980s and during the movement for Caretaker Government in the 1990s, the AL worked with Jamaat leaders and had meetings with Jamaat leaders as mentioned above. In 1980s and afterwards AL, BNP and Jamaat leaders worked together for 7 years against the military government of Major General H.M. Ershad. It is widely known to the people of Bangladesh that now AL is accusing Jamaat leaders of war crimes, which is a very surprising and oppressive attitude of AL.

During these 7 years of struggle for the restoration of democracy, numerous meeting were held between the leaders of Jamaat, BNP and AL in which Jamaat leaders namely Matiur Rahman Nizami, Ali Ahsan Mohammad Mujahid, Mohammad Qamaruzzaman, Abdul Qader Molla and ATM Azharul Islam participated. On behalf of the AL the top leaders late Abdus Samad Azad, Abdul Jalil, Tofail Ahmed, Suranjit Sen Gupta, Amir Hossain Amu and Mohammad Nasim participated. The evidence of those meetings and photographs can be found in press reports from 1984-1990. After the general elections of 1991, on behalf of the Awami League, Mr. Amir Hossain Amu made an offer to Jamaat through Mr. Ali Ahsan Mohammad Mujahid, the present Secretary General of Jamaat to form a coalition government with help of 18 MPs of Jamaat. In return Jamaat was offered 2-3 ministries with a number of seats reserved for women MPs. Jamaat straightway refused the offer of Awami League at that time as it was not conducive for Jamaat.

Throughout the movement for a caretaker government, the leaders of Jamaat and AL addressed press conferences jointly. In a press conference from the precinct of Parliament House in 1996, the then opposition leader Sheikh Hasina (now the Prime Minister), the leader of the Jamaat Parliamentary party and Jamaat President Matiur Rahman Nizami were present. Other top party leaders from Awami League (AL) who attended the meeting were, among others, Mrs. Sajeda Chaudhury, Mr. Suranjit Sen Gupta and others. The national dailies published photographs of that event and the people of Bangladesh know about these meetings and joint press conferences. Now the question may arise that if the top Jamaat leaders were war criminals during 1971 separation movement, then how could the top AL leaders have meetings with top Jamaat leaders together, could arrange press conference in the open field with them for which photographs were taken by the press photographers without any protest and published in daily newspapers in Bangladesh for example the Daily Sangram, the Daily Star etc. More surprisingly, AL could offer Jamaat to form a coalition government with them after 1991 election when they did not get majority seats at the Parliament. The civil society of Bangladesh thinks that AL is behaving like hypocrites with Jamaat (Jalal Uddin, 5 March 2008).

The above political stories and events that show AL's politics is not genuine and fair. It acted with Jamaat like hypocrites as mentioned above. Now they want to hang some top Jamaat leaders for war crimes with the serious criminal and political motive of destroying the party so that in future it has no strong opposition from Jamaat. After getting majority seats in the general election held in December 2008, AL had a noble duty to fulfill all its 
positive promises given to people to develop the country, to reduce price of daily necessities including rice, fertilizer etc., to increase the production of electricity, to reduce the unemployment rate, to increase the literacy rate, to attract foreign invest for industrialization of the country, to beautify the country to attract millions of foreign visitors in Bangladesh. But it has totally failed to keep its promises. It is spending much of its time on the non-issue of trying the top Jamaat leaders for alleged war crimes that happened 39 years ago although Jamaat leaders were not involved in the war crimes at that time.

The visiting European Union Troika delegation leader Ms. Helena Bambasova in response to questions by journalists said that the government enjoys great support from people and that's why it won the last election which was held on 29 December 2008 with a majority votes. She said there was a lot of expectation of people from the AL government and now the government has to fulfill all the good promises given to people to meet the expectations of Bangladeshi people (UNB, Dhaka, 9 June 2009). Indeed, the comments of Her Excellency Ms. Helena were very great and valuable for the AL government and the people of Bangladesh as a whole. But AL is ignoring such valuable advice from intellectuals, diplomats and scholars and to set up war crimes tribunal to persecute only Jamaat leaders to take revenge against them. It is said that AL government is pushed by some conspirators to go on with the war crimes trial against Jamaat and AL government cannot say no to them (Siddiki, 26 April, 2010).

4.1 Statistics of the accused war criminals and parliamentary legislation made by the AL government between 1972-1975 to try the accused.

Table 1 in the Appendix shows that International Crimes (Tribunal) Act was passed in 1973 by the then government of Bangladesh and it identified total 195 war criminals under the Act who were all Pakistani soldiers and officers but they were given an amnesty and repatriated to Pakistan by Bangladesh government under a tripartite agreement signed between Bangladesh-India-Pakistan in 1974. This agreement was signed on April 9, 1974 in New Delhi, India. While given a general amnesty to these 195 war criminals, the PM Sheikh Mujib said: "I want the people of Bangladesh to forget the past and to make a fresh start, ... the people of Bangladesh know how to forgive" (Para 14 of the Agreement).

Bangladesh Collaborators (Special Tribunal) Order 1972 (The Collaboration Order 1972) was passed and more than 100,000 people were arrested under this Order to try them for different types of offences against humanity but ultimately only 752 people were found guilty of different offences and they were imprisoned for different terms. No Jamaat leader or supporter was among these 752 convicted people under the Collaboration Order 1972.

Table 2 in the Appendix shows the number of people who were arrested between 1972-1974 for collaborating with Pakistani Army under the Bangladesh Collaboration (Special Tribunal) Order 1972. The Table shows that more than 100,000 people were arrested by police under this Act for different types of crimes during the separation movement in 1971 and out of them complaint (FIR) was filed only against 37,471 people. However, after investigation charge sheets were not submitted against 34,623 people because police did not find adequate evidence to prosecute them in the Tribunal. Charge sheets where submitted against only 2,848 accused, but after trial only 752 people were found guilty of different offences by the Tribunal and they were imprisoned for different terms in accordance with the nature of crimes. According to the Secretary General of Jamaat, no Jamaat leader or its supporter was convicted in the trial (Daily Sangram, 1 April, 2010). Therefore, a total of 2096 people against whom charge sheets were filed were acquitted as the prosecution failed to prove the case against them beyond reasonable doubt.

It is to be noted that even though 752 people were given penalty for committing offences under the Collaboration Order 1972, general amnesty was given by the Prime Minister Sheikh Mujibur Rahman on 30 November 1973 for some of them. The convicted people who came under the general amnesty were released from the jail. The general amnesty was not applicable on those who were involved in killing, rape, looting and arson. The convicted people who were involved in these four types of offences, were not given general amnesty in 1973 (Daily Sangram, 1 April 2010).

\section{Jamaat Was not Alone to Support Pakistan}

As said earlier Jamaat was not the only political party that supported the cause of a united Pakistan. At that time there were other five political parties along with Jamaat who opposed the separation movement. Besides these political parties, there were thousands of scholars and intellectuals including university professors, doctors, engineers, journalists and religious leaders who also opposed the separation of Bangladesh from Pakistan and this fact is known to the people of Bangladesh. According to Jamaat sources, they thought that Pakistan had been formed from India by a long struggle and a lot of blood and sacrifice of many people against the English colonial 
regime and the Indian Congress party. So, separating Bangladesh with the help of India into two parts would mostly benefit India by allowing her to dominate both the Pakistan and Bangladesh. It was thought by the people of Bangladesh that India could declare Bangladesh as a province of India by force since 65,000 Indian army fought in Bangladesh against Pakistan during separation movement. Anyhow after the 9 months war between the Pakistan government and the Bangladesh Freedom Fighters, the Pakistani Army surrendered and Bangladesh became an independent country on 16 December 1971.

It is widely acknowledged by Bangladeshi people that after Bangladesh was separated from Pakistan, Jamaat leaders cordially supported the independence of Bangladesh and its supporters worked sincerely to protect the independence and sovereignty of Bangladesh and did not maintain any links with the Pakistani government. Since the independence of Bangladesh Jamaat leaders have been working for the welfare of Bangladesh and has been very committed to preserve its sovereignty although some other political parties seem not so sincere and committed to preserve its independence and sovereignty (JIB, 2008).

\section{Violation of Human Rights of Jamaat Leaders}

It is very unfortunate that leaders of a few political parties and a section of the press in Bangladesh in a malicious and revengeful campaign labeled the top leaders of Jamaat as 'war criminals'. This is contrary to all civilized norms and the provisions of local and international human rights legislations and the concept of justice. It is a paramount principle of law that a person is presumed innocent until he is proven guilty by a competent court of law. Hence, before labeling Jamaat leaders as war criminals there must be adequate witnesses and other evidence to prove the case beyond reasonable doubt. It is really surprising that although no leader of Jamaat was listed among the 195 war criminals, they have been termed as war criminals with the motive of political persecution. This is a violation of principles of natural justice and also violation of the fundamental rights and human rights of Jamaat leaders which are guaranteed in the Constitution of Bangladesh and a number of International Conventions including the Universal Declaration of Human Rights and International Covenant on Civil and Political Rights.

All Muslim party alliance in the U.S. known as American Muslim Taskforce on Civil Rights and Election (AMT) organized a press conference on 23 March 2010 in the U.S. They have submitted a memorandum to Ms. Hillary Clinton, the Secretary of State of the U.S. In this memorandum, they mentioned that the Bangladesh government (AL) has become very oppressive to opposition political party members and thousands of them have been killed and wounded. In 2009, 180 people have been killed while in the custody of the law enforcement agency without any trial (Daily Nayadiganta, 23 March 2010).

They also stated in the memorandum that no Jamaat leader was convicted of war crimes and collaboration with Pakistan Army between 1972-1975, but the AL government with political mala fide motive to destroy Jamaat organization, is planning to try top Jamaat leaders for war crimes and collaboration without any evidence. (Daily Nayadiganta, 23 March 2010). It is to be noted that many AL supporters also worked as collaborators (Razakar) of Pakistani Army but they are not prosecuted (Siddiki, 26 April, 2010).

AMT told Hillary Clinton that the people of Bangladesh are facing great danger because of democratic and human rights violations, interference with the judiciary, and the collapse of law and order. Government students named Satro League are seriously assaulting and oppressing thousands of opponent political party students in hundreds of universities and colleges all over the country and killing some of them. The education environment in the country is in serious danger. So, the AMT sought the intervention of the U.S. government to put pressure on the Bangladesh government to stop all types of atrocities and political attacks and killings (RTNN, 23 March, 2010; Daily Amardesh, 23 March 2010).

\subsection{Fair trial is a false propaganda by the AL government: Interview Reports of Prominent Figures}

Recently Daily Sangram has conducted interviews with some prominent figures and intellectuals on the war crimes trial issue in Bangladesh. The prominent persons are: prominent political scientist and former Vice-Chancellor of Dhaka University of Bangladesh, Professor Dr. Emjuddin Ahmad, Former Chief of Bangladesh Army L. General Mahbubur Rahman, prominent journalist and President of National Press Club Bangladesh Showkat Mahmood, Bangladesh Nationalist Party (BNP) Secretary General Khondokar Delwar Hossain, The President of Jammat-e-Islami and former Industry Minister of Bangladesh government Matiur Rahman Nijami, prominent journalist and columnist Sadeq Khan, respected Ex. Speaker of National Parliamnet of Bangladesh Barrister Jamir Uddin Sarker and others.

It is surprising that even before the trial starts AL government Ministers have disclosed the names of alleged war criminals during the 1971 liberation war. Those Ministers includes Deputy Law Minister Advocate Kamrul 
Islam, State Minister Advocate Shahara Khatun, Deputy Health Minister Mojibur Rahman Fakir and others. Professor Dr. Emajuddin Ahmad, the former Vice-Chancellor of Dhaka University Bangladesh said, to disclose the names of alleged war criminals by AL government Ministers proves that the judgment has already been prepared. It is merely a formality to establish a war tribunal, appoint prosecutors and judges and later to announce the judgment, because the judgment has already been prepared. (Shahidul Islam, 28 March 2010).

Respected Ex. Speaker of the National Parliament Barrister Jamiruddin Sarker gave an interview to the Daily Sangram on 28 March 2010 on war crimes trial in Bangladesh. He said it is very unreasonable to find war criminals in the country after releasing 93,000 accused soldiers of Pakistan without trial. AL government cannot get proper evidence to prove the war crime cases 39 years after the war and he doubted there would be fair trial of war criminals. He also said the AL government is targeting the opposition parties in the name of the alleged war crimes after 39 years to weaken their political position, and this is not acceptable (Daily Sangram, 28 March 2010).

Former Chief of Army of Bangladesh L. General Mahbubur Rahman said, "I am not against the war criminal trial. I want transparency, fairness and international standard of law and trial procedure. It is not desirable that someone would be brought to the court for trial only for political motive. By disclosing the list of war criminals before investigation of offence and the trial starts by some AL Ministers, becomes very clear that the AL government is advancing to try the war criminals with pure political motive" (Shahidul Islam, 28 March, 2010).

Prominent journalist and the President of National Press Club in Dhaka, Bangladesh, Mr. Shawkat Mahmood said it is not correct and desirable to call someone a war criminal before investigation into the crimes. Such kind of prior comment and mentioning of names of war criminals before trial starts is contrary to justice and fair trial (Shahidul Islam, 28 March 2010).

Prominent journalist and columnist Sadeq Khan said it is not desirable to decide on the judgment before the trial. It is like throwing weapons against the opponent political party leaders.

AL government actually wants to frighten the Islamist political parties so that they follow their prescription and orders. This is a type of Bakshali attitude which was done by the father of the present Prime Minister Sheikh Hasina in 1975 and for that reason he was assassinated by the Bangladesh Army. To frighten political opponents in Bakshali style, would be dangerous for the AL government. (Shahidul Islam, 28 March 2010).

The Secretary General of Bangldesh Nationalist Party (BNP) said the plan to try alleged war criminals is to achieve political benefit for AL. If AL tries the so-called war criminals for purely political benefit, it would not be fair and would not be acceptable and credible to the world (Shahidul Islam, 28 March, 2010).

Prominent Commander and Organizer of Freedom Fighters in 1971-1975, the Bengali Hero, Kader Siddiqui said the war criminal trial should not be for the achievement of AL's political targets. Fair investigation is needed to identify real war criminals. The AL government is not ready to start a fair trial of war criminals because some of its Ministers have already disclosed the names of war criminals before investigation starts. Nobody should be called a war criminal before the trial is concluded and he is found guilty by the court. (Tipu, 28 March 2010). He also said in an interview that AL government is not willing to have an impartial and international standard trial of the accused (Daily Sangram, 25 March 2010).

Dr. Serajul Islam, a Professor and Chairman of Political Science at Lakehead University in Canada has opined that to ensure fair and impartial trial, the accused of war crimes should be tried under the supervision of United Nations in an International Tribunal or International Court of Justice. Fair and impartial trial is not possible under the AL government in Bangladesh. (Serajul Islam and Saidul Islam, 1 April, 2010).

The President of Jamaat-e-Islami Bangladesh (JIB) Matiur Rahman Nijami has said if the AL government follows United Nations laws, no offences against humanity will be proved against Jamaat. He said this while giving an interview with the Press Association UNB. Mr. Nijami was a very successful Agriculture Minister and later Industry Minister of Bangladesh government during 2001-2006. He expressed his doubts of a free and fair investigation of war crimes in Bangladesh. He said, after taking power the present government's Ministers have given statements against Jamaat and its leaders for war crimes although the statements are not true. Therefore, there is no possibility of having a fair and impartial investigation and trial on war crimes under AL government (Tipu, 28 March 2010).

International Bar Association (IBA) of the UK has submitted a legal opinion to the government of Bangladesh setting out reasons why Bangladesh's legislation for a planned war crimes trial is not compatible with international standards. The lawyers recommended a further 17 changes to the recently amended International 
Crimes (Tribunal) Act 1973 (Bangladesh), arguing that it contains "significant omissions" regarding the protection of the rights of those on trial and an "out of date" definition of war crimes (David, 15 March 2010).

\section{Why Does Jamaat Oppose the International Crimes (Tribunal) Act 1973}

According to Jamaat central body, Jamaat leaders are not afraid of the 1973 Act nor of the trial under the Act. They are in fact afraid of the bias and mala fide political motive of the AL Government to hang certain high profile Islamic political figures as a means of political revenge without proving adequate evidence against them. According to Jamaat, such a conspiracy against Jamaat leaders has been planned by the present government. Jamaat leaders are worried that they may not get a fair trial in the Tribunal under 1973 Act and may not get the fundamental constitutional right to appeal against the decision of the Tribunal to the High Court Division or Appellate Division of the Supreme Court of Bangladesh to challenge the decision of the Tribunal.

In April 2009, the Bangladesh government sought assistance from the UN on how to try war criminals in Bangladesh. Renata Lok Dessallien, the Head of the United Nations in Bangladesh said that they would like to assist Bangladesh by providing the names of international war crimes experts so that Bangladesh may conduct the trial fairly and impartially and does not make any mistake (AFP, 7 April 2009).

United Nations (UN) and Human Rights Watch Asia (HRWA) asked the AL Government to modify the 1973 Act so that it conformed with international standards but AL government has failed to do so. (Peter, 9 July 2009). HRWA Director Mr. Brady also observed that the International Crimes (Tribunal) Act 1973 had many defects. It was not of international standard. It could not ensure a fair trial and justice. Some innocent people might be victims under this law. (Peter, 9 July 2009)

Section 23 of the International War Crimes Act 1973 (The 1973 Act) has taken away basic human rights of the alleged war crimes accused which is guaranteed in the Constitution, Code of Criminal Procedure 1898 and other laws in Bangladesh. It also violates human rights and procedural safeguards provided in the Universal Declaration of Human Rights and the International Covenant on Civil and Political Rights. In June 2009, a delegation from the European Union Troika visited Bangladesh and the press of Bangladesh asked the leader of the Troika delegation Ms. Helena Bambasova some questions regarding the trial of alleged war criminals in Bangladesh under the 1973 Act. In reply she said, "EU thinks that every war crime should be investigated but it has to be done properly, carefully, fairly and transparently" (UNB, Dhaka, 9 June, 2009; Financial Express, 9 June 2009).

The rules of evidence have been made inapplicable under the 1973 Act. Evidence that is normally not admissible in ordinary trials (hearsay evidence and newspaper evidence) have been made admissible under the 1973 Act. The basic features of the 1973 Act which would seriously impede the holding of a fair and impartial trial are as follows;

(i) The provisions of the 1973 Act applies retroactively;

(ii) The appointment of judges to the Tribunal cannot be challenged on the ground of bias;

(iii) The provisions of the Evidence Act 1872 have been made inapplicable;

(iv) The provisions of the Code of Criminal Procedure 1898 have been made inapplicable;

(v) Right of appeal to the superior courts in Bangladesh has not been given;

(vi) Judicial Review has been denied; and

(vii) The Act applies only to war criminals who opposed the separation movement, the freedom fighters who committed murder and other offences are not punishable under the 1973 Act. (JIB, 2008).

In the war crimes trial, it is crucial to find enough evidence against the accused to prove the case beyond reasonable doubt as stated above. Now it is a great challenge for AL government to get adequate evidence to find the accused guilty after 39 years. D'Costa, a prominent writer and human rights activist, emphasized the collection of impartial and correct evidence to prosecute the war criminals (D'Costa, 9 July 2009).

Section 101 to 105 of the Evidence Act 1872 (Bangladesh) places the burden on the prosecution to prove the case with adequate evidence. In criminal law it is the duty of the prosecution to prove the guilt of the accused beyond reasonable doubt with adequate evidence. If the prosecution fails to prove the case beyond reasonable doubt, the accused will be acquitted. However, section 23 of the 1973 Act has excluded the application of the Evidence Act, 1872 (Abu Rawsab, 29 May 2010). So, the 1973 Act goes against Article 11(1) of the Universal Declaration of Human Rights and Article 14(2) of the International Covenant on Civil and Political Rights. 
Therefore, under this Act a fair trial and a fair judgment is not possible (Abu Rawsab, 29 March 2010). Section 19(1) of the 1973 Act provides that newspaper articles will be admitted as evidence.

AL government has given the Tribunal power and jurisdiction which is equivalent to the High Court. Such a decision has political mala fide motive so that the accused cannot appeal to the High Court. Even the 1973 Act does not allow the accused to appeal to the Appellate Division of the Supreme Court of Bangladesh. This can be termed as a gross violation of fundamental human rights guaranteed in international law for the alleged accused of war criminals in Bangladesh (International Covenant on Civil and Political Rights).

It is important to mention at this point that recently the Minister of Law and Justice in Bangladesh after coming back from U.S. visit in the first week of April 2010 declared that we are not going to try the criminals during liberation war in 1971 for 'war crimes' but for 'crimes against humanity'. Recently he has also declared that in Bangladesh there is no war criminal and this has been demanded by Jamaat for a long time. As the present AL government has decided to try the criminals (during 1971 freedom fighting war) for 'crimes against humanity', it should try the offences under the Penal Code of Bangladesh in the normal court. 'Crimes against humanity' includes murder, rape, arson and looting. These four types of offences are available in the Penal Code of Bangladesh and adequate punishment has been prescribed for the criminals. Jamaat demands the trial of criminals for 'crimes against humanity' under the Penal Code of Bangladesh in the normal court which might be fair and impartial but the trial in the War Crimes Tribunal (formed under the International War Crimes (Tribunal) Act 1973, Bangladesh) will not be fair and impartial as its judges and investigation committee members are hardcore supporters of AL government.

\section{Conclusion}

The first Prime Minister of Bangladesh Sheikh Mujibur Rahman (the father of the present Prime Minister Sheikh Hasina) declared an amnesty for all the people who were involved in war crimes or collaborated with the Pakistani Army during his rule between 1972-1975. His intention was that the people of Bangladesh wanted independence of Bangladesh and that was achieved. So, the next task was to unite the people from all parties and to take their assistance to develop the war-torn country. To develop the country, assistance is needed from all the opposition political parties. That was a great political philosophy of the father of the present Prime Minister of Bangladesh (Jalil Uddin, 5 February 2008).

The separation movement happened 39 years ago and it is normal that some people may oppose the separation of a country into two parts as happened in Bosnia, Russia, India etc. However, the people who are involved in war crimes, genocide, rape etc. must be tried and punished as soon as possible. For the case of Bangladesh it was not done, rather the 195 Pakistani soldiers who were convicted as war criminals were forgiven and repatriated to Pakistan under a three country agreement in 1974 and collaborators were given amnesty in 1975 as stated above.

The present government after 39 years has reopened the settled chapter to punish the war criminals, but it is very difficult to get adequate evidence to find the accused guilty after 39 years because most of the eye witnesses have died or become so old that their memory does not work properly and many of the documentary evidence has been destroyed or lost. The accused cannot be convicted and punished merely based on newspaper information which AL government wants. This will work contrary to the fundamental principle of criminal law and law of evidence that 'the offence must be proved beyond reasonable doubt' to convict an accused. Besides, AL government wants to try and punish only top Jamaat leaders (who claim that they were not involved in war crimes) although more than five political parties and thousands of independent intellectuals and scholars opposed the separation movement as stated earlier in my discussion. This is not fair to try the leaders of one political party only while declaring amnesty to other political party leaders who also committed the same offence. This is known as politicizing the event and taking revenge of an opponent political party which is getting good support from people for its democratic and social activities.

Prominent lawyers of Bangladesh have protested against the International War Crimes Tribunal which has recently been established by the AL government in Bangladesh and said this Tribunal is illegal. They have questioned the validity of the International War Crimes (Tribunal) Act 1973 (Bangladesh). They also questioned the impartiality and integrity of the judges, investigation committee and the prosecution team appointed under this Act, because they are all hardcore supporters of the present government. They said that most of the sections of the 1973 Act are contrary to the Constitution of Bangladesh, Penal Code, Code of Criminal Procedure and the evidence Act of Bangladesh. Article 102 of the Constitution of Bangladesh gives right to appeal and judicial review to the High Court Division and Appellate Division of the Supreme Court of Bangladesh, but this Article has been excluded by the 1973 Act with a political mala fide motive (Farhan, 23 April, 2010). 
The present AL government won at the general election held on 29 December 2008 where it got majority seats at the Parliament. Before the general election, the party promised to people to reduce the price of daily necessary things including fertilizer and rice; to create employment opportunities for unemployed people by setting up new industries, to attract foreign investment, to stop corruption and terrorism, to solve the problem of electricity deficiency which is a serious problem in Bangladesh where temperature is between 35 to $40^{\circ} \mathrm{C}$ in summer season, to give primary education to hundred percent children in the county etc. Instead of spending precious time on the settled issue on war crimes, the government should work hard to fulfill the promises given to the people before election and to satisfy the people so that this government can win in the next general election again. I suggest that further research should be done on the 'war crimes tribunal issue' in Bangladesh as the AL government has already started investigation process on the listed war criminals. The findings of the Tribunal would be reported later and further research might be conducted on the fairness and impartiality of the findings on the Tribunal.

\section{References}

Abu Rawsab. (29 March 2010). Ten reasons why the war crime tribunal is bound to be kangaroo court. See,

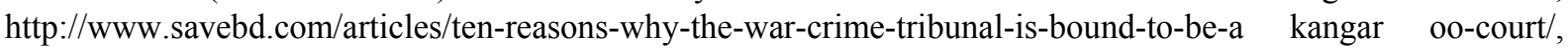
accessed on the web site on 30.03.2010.

Abu Rawsab. (13 February 2010). Are Jamaat-Shibir Terrorists or Victims of Terrorism. See, www.sonarbangladesh.com/print.php?id=1993, accessed on the web site on 05.03.2010.

AFP. (7 April, 2009). UN to help Bangladesh crimes trial planning. See, http://www. google.com/ afp/article/AleqMSi8DOGtdottAJaQhtR_org4cmvwow, accessed to the web site on 10.4.2010.

AI. (23 February 2010). Amnesty International: Politically Motivated Arbitrary Arrests in Educational Institutions Hamper Impartial Investigation of Campus Violence. 23 February 2010, AI Index: ASA 13/005/2010

D'Costa, Bina. (9 July 2009). Frozen in Time? The War Crimes Trial in Bangladesh. See, http://www.asiapacific.anu.edu.au/blogs/southasiamasala/2009/07/09/frozen-in-time-the-war-crimes-trial-in-ban, accessed to the web site on 10.03.2010.

Daily Sangram. (1 April 2010). Statement of Ali Ahsan Muhammad Mujahid in Press Conference: AL government is staging imaginary war crimes trial drama being failed to face Jamaat politically. See, $\mathrm{http}: / /$ www.dailysangram.com/news_details.php?news_id=28318. Accessed to the web site on o1.04.2010. It is to be noted that Mr. Ali Ahsan Muhammad Mujahid is the Secretary General of Jamaat-e-Islami Bangladesh (Jamaat).

Daily Amardesh. (23 March 2010). The Concern of Muslim Leaders in the U.S. for Human Rights Situation in Bangladesh. See, http://www.amardesh-online.com/pages/details/2010/03/24/24188, accessed to the web site on 26.03.2010.

Daily Sangram. (23 March 2010). TV Interview: AL Government is not ready for war criminal trial, it is necessary to have fair and international standard trial. The Daily Sangram, 23 March 2010. See, http://www.dailysangram.com/news_details.php?ness_id=27905, accessed to the web site on 25.03.2010.

Abdul Kader. (25 March 2010). Bengali Hero Kader Siddiqui in TV Interview: AL government is not ready for war crimes trial; fair and international standard trial needed. See, http://www.dailysangram.com/ news_details.php?news_id=27905. Accessed to the web site on 25.03.2010.

Daily Sangram. (28 March 2010). Barrister Jamiruddin Sarker to the journalists: to try war criminals with an intention to weaken the opposition parties, would not be acceptable and credible. See, http://www.dailysangram.com/news_details.php?news_id=28071. Accessed to the web site on 28.03.2010.

David, Bergman. (15 March 2010). War Crimes Law Falls Short. bdnews24.com, See, http://www.bdnews24.com/details.php?id=155832\&cid=2, accessed to the web site on 20.03.2010.

Dummett, Mark. (30 June 2008).Bangladesh war crimes trial stirs tension. BBC News, Dhaka.

Farhan, Saqib. (23 April 2010),. Debate on International War Crimes Tribunal, Bangladesh. See, http://www.sonarbangladesh.com/article.php?ID=2447, accessed on the web site on 28 April 2010.

Financial Express. (9 June 2009). EU stresses clear war crimes probe. See, $\mathrm{http} / / / \mathrm{www}$.thefinancialexpress-dd.com/2009/06/09/69218.html, accessed to the web site on 15.03.2010.

Hossain, Emran. (16 May 2009). The Daily Star Interviews Amnesty International (AI) Asia Pacific Program Director Sam Zarifi. The Daily Star, 16 May 2009. See at http://www.thedailystar.net/newsDesign/story-details.php?nid=208, accessed to the web site on 14.03.2010. 
IAN. (8 June 2009). Dhaka, Islamabad Spar Over 1971 War Crimes Trial: Report. See, http://www.thiandian. com/newsportal/world-news/dhaka-islamabad-spar-over-1971-war-crimes-trial-report_100202221.html, accessed to the web site on 13.03.2010.

Indo-Pak Joint Agreement, 28 August 1973.

Jalal Uddin. (5 February, 2009). Not Just Collaborators, Baksalite and the Rakhkhi-Bahini Elements Too. News Forum Bangladesh. See, http://www.Bangladesh-web.com/view.php?hidRecord=186352. Accessed to the web site on 10.03.2010. It is to be noted that Dr. Jalal Uddin Khan is a prominent Professor of English Literature in the University of Kuwait in the Middle East.

JIB. (2008). War Crimes Law and Constitutionalism, Dhaka: Al-Falah Printing Press.

Peter, Marijke, (9 July 2009). Fair War Crimes Trial in Bangladesh?

RTNN. (23 March 2010). The concern of AMT with law and order situation in Bangladesh, memorandum to Hillary. See, http://www.rtnn.net/details.php?id=22885\&p=1\&s=9, accessed to the web site on 23.03.2010.

RTNN. (25 March, 2010). Announcement of 6 member Investigation Committee for War Criminal Tribunal in Bangladesh. See, http://www.rtnn.net/details.php?id=22974\&p=1\&s=3, accessed to the web site on 25.03.2010.

Serajul Islam, and Saidul Islam, (1 April, 2010), War Crimes Tribunal in Bangladesh: A Contested Move. http://www.sonarbangladesh.com/article.php?ID=2296, accessed to the web site on 27 April 2010. It is to be noted that Dr. Syed Serajul Islam is a Professor and Chairman of Political Science at Lakehead University in Canada and Dr. M. Saidul Islam is an Assistant Professor of Sociology at Nanyang Technological University, Singapore.

Serajul Islam and Saidul Islam. (2010). War Crimes Tribunal in Bangladesh: A Miscarriage of Justice. JUST Commentary: International Movement for a Just World, Vol. 10(4), April 2010, at p. 3.

Shahidul Islam. (28 March 2010). The trial of war crimes is questionable now, the accused' names have been disclosed before investigation, the judgment of the suit is given before trial. See, http://www.dailysangram.com/news_details.php?news_id=28070, accessed to the web site on 28.03.2010.

Siddiki, Rejoan. (26 April, 2010). They were not criminals although they were Razakar. See, http://www. sonarbangladesh.com/article.php?ID=2457, accessed to the web site on 26.04.2010.

The Simla Agreement, $2^{\text {nd }}$ July 1972.

Tipu, Faheh Ali. (28 March 2010). The propaganda and reality of war crimes: purely politically motivated trial. See, http://www.dailysangram.com/news_details.php?news_id=28073, accessed to the web site on 28.03.2010.

Tripartite agreement, (1974). Bangladesh-India-Pakistan Agreement 1974. It was signed in New Delhi on April 9 , 1974.

UNB, Dhaka. (9 June 2009). War crime trial must be done properly: EU Troika. The New Nation, 9 June, 2009.

Zahid Zamir. (16 February 2010). Madam Prime Minister, where are you taking us? See, http://www. sonarbangladesh.com/article.php?ID=2005, accessed on the web site on 27 April 2010.

Zeeness. (2008). War Crimes trial not closed, Bangladesh tells Pakistan.

\section{Legislation}

Bangladesh Collaborators (Special Tribunal) (Repeal) Ordinance, 1975.

Bangladesh Collaborators (Special Tribunal) Order 1972.

Code of Criminal Procedure 1898 (Bangladesh)

Constitution of Bangladesh (Bangladesh)

Evidence Act 1872

International Covenant on Civil and Political Rights (UN)

International Crimes (Tribunal) Act 1973 (Bangladesh)

Penal Code (Bangladesh)

Universal Declaration of Human Rights (UN) 
Table 1. Parliamentary laws passed in relation to war crimes and collaboration during 1972-1975

\begin{tabular}{|l|c|l|l|}
\hline Parliamentary laws & $\begin{array}{l}\text { The year in } \\
\text { which the law } \\
\text { was passed }\end{array}$ & $\begin{array}{l}\text { Number of People found guilty of war } \\
\text { crimes }\end{array}$ & The year in which the law was repealed \\
\hline $\begin{array}{l}\text { International Crimes } \\
\text { (Tribunal) Act }\end{array}$ & 1973 & $\begin{array}{l}\text { In } 1973 \text { total 195 Pakistani soldiers } \\
\text { were identified as war criminals. No } \\
\text { Jamaat leaders or supports name was } \\
\text { not in the list. }\end{array}$ & $\begin{array}{l}\text { This law was not formally repealed but its } \\
\text { implementation was stopped in 1974 by signing } \\
\text { the angartite agreement known as } \\
\text { "Bangladesh-India-Pakistan Agreement" 1974 } \\
\text { which was sighed by the governments of the three } \\
\text { countries in New Delhi. Amnesty was granted to } \\
\text { these 195 war criminals and they were repatriated } \\
\text { to Pakistan under the tripartite agreement. }\end{array}$ \\
\hline $\begin{array}{l}\text { Bangladesh } \\
\text { Collaborators (Special } \\
\text { Tribunal) Order }\end{array}$ & 1972 & $\begin{array}{l}\text { The law was repealed in 1975 by passing } \\
\text { Bangladesh Collaborators (Special Tribunal) } \\
\text { (Repeal) Ordinance 1975. }\end{array}$ \\
\hline
\end{tabular}

Source: Abu Rawsab, 13 February, 2010; JIB, 2008; Daily Sangram, 1 April 2010.

Table 2. The statistics of number of people arrested, accused, tried and punished for war crimes and collaboration between 1972-1975.

\begin{tabular}{|l|l|l|l|}
\hline $\begin{array}{l}\text { Number of people } \\
\text { arrested }\end{array}$ & $\begin{array}{l}\text { Number of people against whom } \\
\text { criminal case filed }\end{array}$ & $\begin{array}{l}\text { Number of people found guilty of } \\
\text { offences and punished }\end{array}$ & $\begin{array}{l}\text { After trial number of people } \\
\text { acquitted }\end{array}$ \\
\hline $\begin{array}{l}\text { More than 100,000 people } \\
\text { were arrested. }\end{array}$ & $\begin{array}{l}37,471 \text { people were accused for } \\
\text { different types of criminal } \\
\text { offences. } \\
\text { But, charge sheets were not filed } \\
\text { against 34,623 for lack of } \\
\text { evidence. }\end{array}$ & $\begin{array}{l}\text { Charge sheets were filed against 2,848 } \\
\text { accused and criminal trial started against } \\
\text { them. After trial in the Tribunal only 752 } \\
\text { people were found guilty of different } \\
\text { offences and were imprisoned for } \\
\text { different terms. }\end{array}$ & $\begin{array}{l}\text { A total of } 2096 \text { people against } \\
\text { whom acquitted as no offence } \\
\text { could be proved against them. }\end{array}$ \\
\hline
\end{tabular}

Source: Abu Rawsab, 13 February, 2010; RTNN, 23 March 2010; Daily Sangram, 1 April 2010. 